\title{
Effect of Biostimulants Sprays on Growth and Flowering of Cut Gladiolus (Gladiolus grandiflorus L.) Cv. Arkaamar
}

\author{
Ravikumarbolagam $^{1^{*}}$ and Seenivasan Natarajan ${ }^{2}$ \\ ${ }^{1}$ College of Horticulture, Sri KondaLaxman Telangana State Horticultural University, \\ Rajendranagar, Hyderabad, Telangana, India-500030 \\ ${ }^{2}$ Sri KondaLaxman Telangana State Horticultural University, College of Horticulture, \\ Mojerla, Wanaparthy, Telangana, India-509382 \\ *Corresponding author
}

\section{A B S T R A C T}

\section{Keywords}

Biostimulants, Spike, Humic acid, Arkaamar and Gladiolus

Article Info

Accepted:

18 August 2019 Available Online: 10 September 2019
The present investigation "Studies on the effect of biostimulants on growth and flowering of cut gladiolus (Gladiolus grandiflorus L.) Cv. Arkaamar" was carried out at the Floricultural Research Station, Rajendranagar of Sri Konda Laxman Telangana State Horticultural University, Hyderabad during September 2017 to February, 2018. The experiment was laid out in Randomized Block Design replicated thrice with eleven treatments. The results on vegetative parameters revealed that among different pre soaking and foliar sprays of bio stimulants at 30 and 45 days after corm sprouting. The application of Humic acid at $4 \mathrm{ml} / 1\left(\mathrm{~T}_{8}\right)$ recorded significantly minimum number of days for $50 \%$ and $100 \%$ sprouting of corms(7.20 days), maximum plant height at 30 , 45 and 60 days after corm sprouting $(32.93 \mathrm{~cm}, 51.26 \mathrm{~cm}$ and $81.53 \mathrm{~cm}$ respectively), longer leaf length $(39.80 \mathrm{~cm})$ and broader leaf width with respect to floral parameters except diameter of spike. Humic acid $4 \mathrm{ml} / 1$ treatment resulted in earlier spike emergence (57.23 days), longer spike length, more number of florets per spike (13.60), increased length $(9.90 \mathrm{~cm})$ and diameter of floret, fresh weight of floret $(3.73$ $\mathrm{g}$ ), duration of flowering(16.53 days), spike longevity on the plant, number of spikes plant $^{-1}$, number spikes per plot and further maximum number of spikes ha ${ }^{-1}(1.83$ lakhs) was also recorded.

\section{Introduction}

Gladiolus (Gladiolus grandiflorus L.) generally called as sword lily due to its sword shaped leaves. A member of family Iridaceae, originated from South Africa. It has great economic value and social appeal for cut flower trade and much valued by the aesthetic world for beauty loving people because of its prettiness and unparallel elegance (Sadhu and Bose., 1973). Commercially propagated by corms, florets open sequentially from the base of the rachis, and extension of longevity of these florets helps in maintaining the economic value of these flowers for a longer time. They are widely used as artistic 
garlands, floral ornaments, bouquets etc. The long flower spikes are excellent as cut flower for table decoration when arranged in vases.

In Telangana total area under flower crops was 2,950 ha with production of loose and cut flowers 10,055 and 9,000 MT respectively (NHB, Data base 2016-17).The growing demand for food, feed, fuel, fiber, and raw materials and the increasing resource depletion and ecosystem degradation impose the use of more sustainable methods in the agriculture production systems. Several organic products called "biostimulants" are now available in the market to make agriculture more sustainable (www.biostimulants.eu). Plant biostimulants contain substance(s) and/or micro-organisms whose function when applied to plants or the rhizosphere may stimulate natural processes to enhance/benefit nutrient uptake, nutrient efficiency, tolerance to abiotic stress, and crop quality (Kauffman et al., 2007).Keeping in the view the need and importance of bio stimulants, the present investigation were conducted with the objective of studying the effect of biostimulants namely; Triacontanol, Cytozyme, Biozyme, Humic acid and Fulvic acid on growth and floweringof cut gladiolus.

\section{Materials and Methods}

The experimental site is located at Floricultural Research Station(Agricultural Research Institute), Rajendranagar, Hyderabad. Located at an altitude of $542.3 \mathrm{~m}$ above mean sea level with geographical bearing of $17.19^{\circ} \mathrm{N}$ latitude and $78.23^{\circ} \mathrm{E}$ longitude. The experimental site falls under subtropical climate zone with an average rainfall of $800 \mathrm{~mm}$ per annum, red sandy loam soil with good drainage facility and low water holding capacity. Meteorological data pertaining to temperatures maximum and minimum $\left(30.18^{\circ} \mathrm{C}\right.$ and $15.25^{\circ} \mathrm{C}$ respectively), relative humidity (AN $42.56 \%$, FN $88.95 \%$ ) and sunshine hours (7.56) in monthly averages recorded during the investigation period. The experiment was laid out in a Randomized Block Design (RBD) with eleven treatments replicated thrice. The field lay out and randomization of treatments with $1.5 \times 1.5 \mathrm{~m}$ $\left(2.25 \mathrm{~m}^{2}\right)$ plots were used per treatments carried out as per the statistical methods given by PanseandSukhatme (1985). Organic manure like well decomposed farmyard manure 5 $\mathrm{kg} \cdot \mathrm{plot}^{-1}$ were incorporated into all the experimental plots uniformly as basal application and N, P and K @ $25: 35: 35 \mathrm{~kg}$. acre $^{-1}$ were applied in form of Ammonium sulphate, Single super phosphate and Murate of potash respectively mixed well. Ammonium sulphate applied in 3 split doses, the first dose as basal application and other two split doses at 3 leaf stage and 6 leaf stage.

Solutions of $2 \mathrm{ml}$ and $4 \mathrm{ml}$ of biostimulants were prepared in $1000 \mathrm{ml}$ volumetric flask by dissolving calculated quantity of biostimulants in 0.998 and 0.996 litre distilled water respectively. The Biostimulants are applied three times i.epre soaking of corms (1hr) before planting and foliar application on 30 and 45 days after corm sprouting. Uniformly growing five plants at random from each plot were tagged in each replication for recording different observations.

The details of the observations recorded during course of investigation were given in tables. Observations on growth and floral parameters were recorded at fixed interval and the mean data were subjected to statistical analysis. The treatment details are furnished below

T1-Triacontanol@2ml/L, T2-Triacontanol@ 4ml/L, T3-Cytozyme @ 2ml/L, T4-Cytozyme @ 4ml /L, T5-Biozyme @ 2ml/L, T6-Biozyme @ 4ml/L, T7-Humic acid @ 2ml/L, T - Humic acid@4ml/L, T9-Fulvic acid @ 2ml/L, T $10^{-}$ Fulvic acid@4ml/L, T11-Control. 


\section{Results and Discussion}

The effect of bio stimulants on growth, flowering was assessed on cut gladiolus cv. Arka Amar and the results of the experiments are presented in Table 1,2 and 3.

The progressive data was recorded on growth studies viz. number of days taken to $50 \%$ sprouting and $100 \%$ sprouting, plant height, number of leaves per plant, leaf length, leaf width and leaf area as effected by various biostimulant treatments.

The number of days taken for $50 \%$ and $100 \%$ sprouting of corms was significantly influenced by different pre-soaking treatments. Among the different treatments, application of Humic acid at $4 \mathrm{ml} / 1 \quad\left(\mathrm{~T}_{8}\right)$ resulted in early spouting of corms presented in fig.1. Humic acid may have accelerated the uptake of water by the swelling corm during the initial stage of imbibitions which in turn activatedcertain essential enzymeswhich ensure normal sprouting to take place. These results are line with earlier findings of Bashir et al., (2016) who reported higher sprouting (4\%) with the application of humic acid at $3 \mathrm{ml}$ in combination with NPK, similarly Ahmad et al., (2013) also reported that with three applications of HA and NPK resulted in earliest 50\% sprouting (8.4 days) in gladiolus.

Irrespective of the treatments plant height increased gradually from 30 days after corm sprouting to spike emergence time. The treatment Humic acid at $4 \mathrm{ml} / \mathrm{l}\left(\mathrm{T}_{8}\right)$ recorded significantly maximum plant height at 30 Days after corm sprouting $(32.93 \mathrm{~cm}), 45$ DACS $(51.26 \mathrm{~cm})$ and 60 DACS $(81.53 \mathrm{~cm})$ respectively which was followed by Humic acid $2 \mathrm{ml} / 1\left(\mathrm{~T}_{7}\right)(76.2 \mathrm{~cm})$ presented in fig. 2 . The increased plant height with the application of humic acid might be due to enhanced cell elongation and the plant growth regulator activity of humic substances, similar results were reported by Cacco and Dell Angola (1984). Significantly lengthier leaves (39.80 $\mathrm{cm})$ was produced from the humic acid at $4 \mathrm{ml} / \mathrm{l}$ followed by Humic acid at $2 \mathrm{ml} / 1$ (37.60 $\mathrm{cm}$ ) and effect of bio stimulants on the leaf width of cut gladiolus was significantly broader $(3.73 \mathrm{~cm})$ in Humic acid treatment at $4 \mathrm{ml} / 1$ which was followed by Humic acid at $2 \mathrm{ml} / 1$ i.e $\mathrm{T}_{7}(3.36 \mathrm{~cm})$. Also the results revealed that maximum leaf area $\left(132.66 \mathrm{~cm}^{2}\right)$ was recorded Humic acid at $4 \mathrm{ml} / \mathrm{L}-\mathrm{T}_{8}$ a higher length and breadth of leaves due to the presence of precursors of growth substance viz., IAA in humic acid, could have increased the length and breadth of leaves as reported by Cosenova et al., (1990).

The data on the number of days taken for spike emergence revealed that there was significant difference among the treatments with application of biostimulants. Spike emergence was earlier in $4 \mathrm{ml} /$ humic acid treatment (57.23 days).

It might be due to the gibberellin like activity of humic acid.These findings are in line with those earlier findings of Vaughan et al., (1985); Azza et al., (2012); Pritam et al., (2010)The spike length was found to be maximum in humic acid at $4 \mathrm{ml} / \mathrm{l}-\mathrm{T}_{8}$ spray $(96.90 \mathrm{~cm})$ which was followed by $\mathrm{T}_{7}$ i.eHumic acid at $2 \mathrm{ml} / 1$ (90.70 $\left.\mathrm{cm}\right)$ represented in fig.3.Humus substances present in humic acid could have mobilized the reserve food materials to the sink through increased activity of hydrolyzing and oxidizing enzymes, this in turn could have assisted for greater spike length (Mato and Mendez., 1970).

There is no significant difference among the treatments with regarding the diameter of spike however, the results revealed that there was slight increase in diameter of spike due to various pre soaking and foliar sprays of bio stimulants (Bashir et al., 2016). 
Table.1 Effect of bio stimulants on growth parameters of cut gladiolus cv. Arkaamar

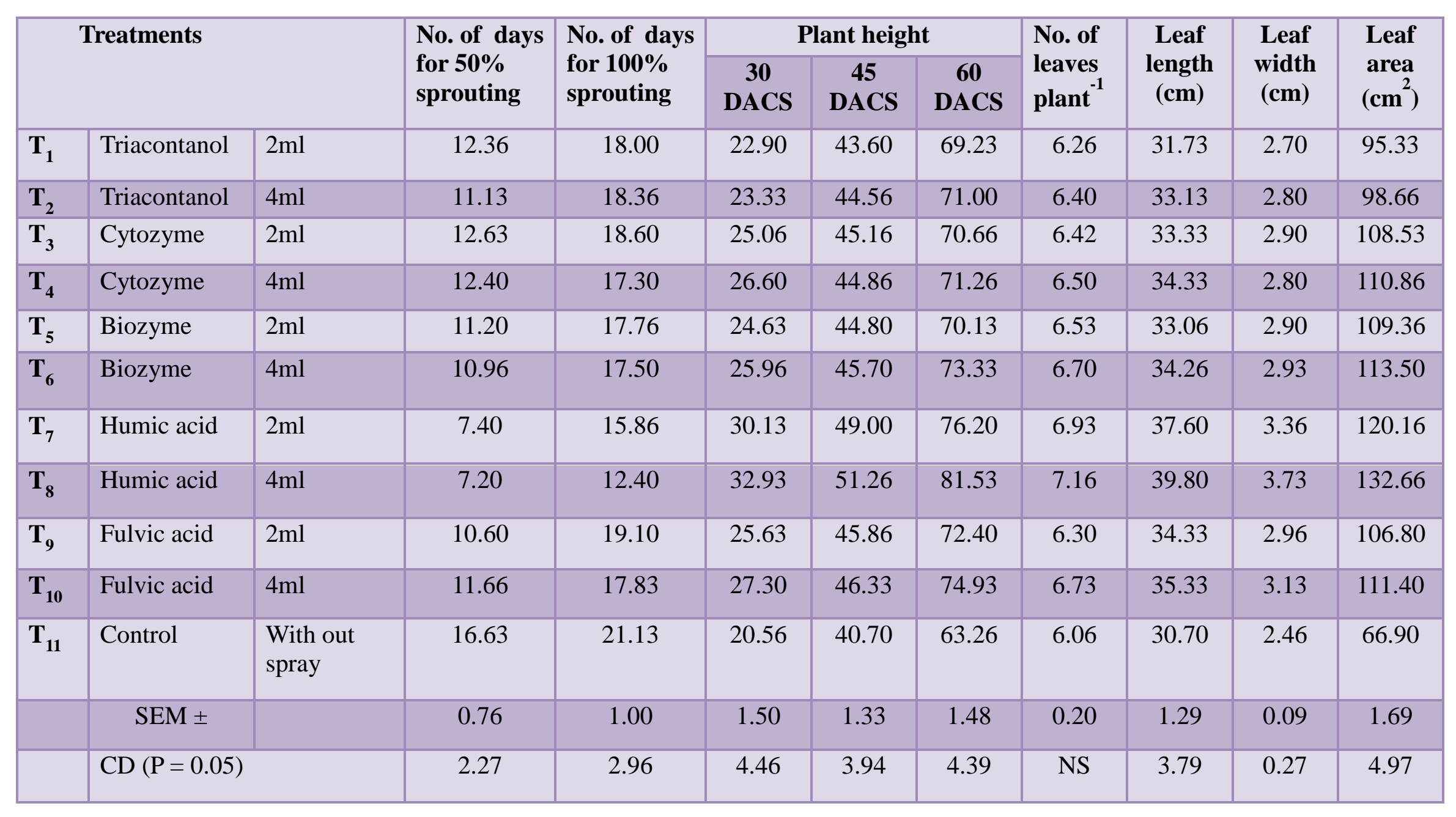


Table.2 Effect of bio stimulants on floral parameters of cut gladiolus cv. Arkaamar

\begin{tabular}{|c|c|c|c|c|c|c|c|c|}
\hline \multicolumn{3}{|c|}{ Treatments } & \multirow{2}{*}{$\begin{array}{c}\text { Days to spike } \\
\text { emergence }\end{array}$} & \multirow{2}{*}{$\begin{array}{c}\begin{array}{c}\text { Duration of } \\
\text { flowering (No.) }\end{array} \\
12.16\end{array}$} & \multirow{2}{*}{$\begin{array}{c}\begin{array}{c}\text { Spike length } \\
(\mathbf{c m})\end{array} \\
79.20\end{array}$} & \multirow{2}{*}{$\begin{array}{c}\text { Diameter of } \\
\text { spike (cm) } \\
3.50\end{array}$} & \multirow{2}{*}{$\begin{array}{c}\begin{array}{r}\text { Length of } \\
\text { floret }(\mathbf{c m})\end{array} \\
8.23\end{array}$} & \multirow{2}{*}{$\begin{array}{c}\begin{array}{c}\text { Diameter of } \\
\mathbf{2}^{\text {nd }} \text { floret }(\mathbf{c m})\end{array} \\
7.23\end{array}$} \\
\hline $\mathbf{T}_{1}$ & Triacontanol & $2 \mathrm{ml}$ & & & & & & \\
\hline $\mathbf{T}_{2}$ & Triacontanol & $4 \mathrm{ml}$ & 69.00 & 12.73 & 80.93 & 3.60 & 8.30 & 7.30 \\
\hline $\mathbf{T}_{3}$ & Cytozyme & $2 \mathrm{ml}$ & 66.10 & 12.93 & 80.26 & 3.36 & 8.33 & 7.33 \\
\hline $\mathbf{T}_{4}$ & Cytozyme & $4 \mathrm{ml}$ & 67.40 & 13.10 & 81.23 & 3.50 & 8.50 & 7.36 \\
\hline $\mathbf{T}_{5}$ & Biozyme & $2 \mathrm{ml}$ & 66.56 & 13.06 & 81.40 & 3.43 & 8.60 & 7.50 \\
\hline $\mathbf{T}_{6}$ & Biozyme & $4 \mathrm{ml}$ & 64.76 & 14.00 & 82.40 & 3.53 & 8.83 & 7.83 \\
\hline $\mathbf{T}_{7}$ & Humic acid & $2 \mathrm{ml}$ & 61.26 & 14.80 & 90.70 & 3.66 & 9.56 & 7.96 \\
\hline $\mathbf{T}_{8}$ & Humic acid & $4 \mathrm{ml}$ & 57.23 & 16.53 & 96.90 & 3.73 & 9.90 & 8.73 \\
\hline $\mathbf{T}_{9}$ & Fulvic acid & $2 \mathrm{ml}$ & 66.06 & 13.43 & 82.23 & 3.53 & 8.66 & 7.40 \\
\hline $\mathbf{T}_{10}$ & Fulvic acid & $4 \mathrm{ml}$ & 65.53 & 14.16 & 83.63 & 3.56 & 8.90 & 7.90 \\
\hline $\mathbf{T}_{11}$ & Control & $\begin{array}{l}\text { With out } \\
\text { spray }\end{array}$ & 74.63 & 9.73 & 75.23 & 3.23 & 8.06 & 6.66 \\
\hline & $\mathrm{SEM} \pm$ & & 1.60 & 0.41 & 1.44 & 0.15 & 0.26 & 0.21 \\
\hline & $\mathrm{CD}(\mathrm{P}=0.05)$ & & 4.70 & 1.20 & 4.23 & NS & 0.77 & 0.64 \\
\hline
\end{tabular}


Table.3 Effect of bio stimulants on floral parameters of cut gladiolus cv. Arkaamar

\begin{tabular}{|c|c|c|c|c|c|c|c|c|}
\hline \multicolumn{3}{|c|}{ Treatments } & $\begin{array}{c}\begin{array}{c}\text { No. of florets } \\
\text { spike }^{-1}\end{array} \\
10.50\end{array}$ & $\begin{array}{c}\begin{array}{c}\text { Fresh weight } \\
\text { of floret (g) }\end{array} \\
3.10\end{array}$ & $\begin{array}{c}\begin{array}{c}\text { Spike longevity } \\
\text { on the plant } \\
\text { (days) }\end{array} \\
13.30\end{array}$ & $\begin{array}{c}\begin{array}{c}\text { No. of spikes } \\
\text { plant }^{-1}\end{array} \\
1.03\end{array}$ & $\begin{array}{c}\text { Spike yield } \\
\text { plot }^{-1} \text { (spike } \\
\text { No./plot) } \\
31.13\end{array}$ & $\begin{array}{c}\begin{array}{c}\text { Spike yield ha } \\
\text { (spike lakh } \\
\text { No./ha) }\end{array} \\
1.38\end{array}$ \\
\hline $\mathbf{T}_{2}$ & Triacontanol & $4 \mathrm{ml}$ & 11.42 & 3.26 & 14.10 & 1.30 & 31.16 & 1.38 \\
\hline $\mathbf{T}_{3}$ & Cytozyme & $2 \mathrm{ml}$ & 10.50 & 3.13 & 13.90 & 1.30 & 31.33 & 1.39 \\
\hline $\mathbf{T}_{5}$ & Biozyme & $2 \mathrm{ml}$ & 10.30 & 3.16 & 15.23 & 1.16 & 32.33 & 1.43 \\
\hline$T_{6}$ & Biozyme & $4 \mathrm{ml}$ & 12.60 & 3.20 & 15.66 & 1.26 & 33.33 & 1.48 \\
\hline $\mathbf{T}_{7}$ & Humic acid & $2 \mathrm{ml}$ & 12.00 & 3.46 & 16.20 & 1.56 & 37.33 & 1.65 \\
\hline $\mathbf{T}_{8}$ & Humic acid & $4 \mathrm{ml}$ & 13.60 & 3.73 & 18.32 & 2.0 & 41.33 & 1.83 \\
\hline $\mathbf{T}_{11}$ & Control & $\begin{array}{l}\text { With out } \\
\text { spray }\end{array}$ & 10.20 & 2.63 & 12.04 & 1.00 & 28.00 & 1.24 \\
\hline & $\mathrm{SEM} \pm$ & & 0.47 & 0.12 & 0.67 & 0.09 & 1.03 & 4.67 \\
\hline & $\mathrm{CD}(\mathrm{P}=0.05)$ & & 1.40 & 0.35 & 1.99 & 0.27 & 3.06 & 1.36 \\
\hline
\end{tabular}




\section{Imposition of treatments}

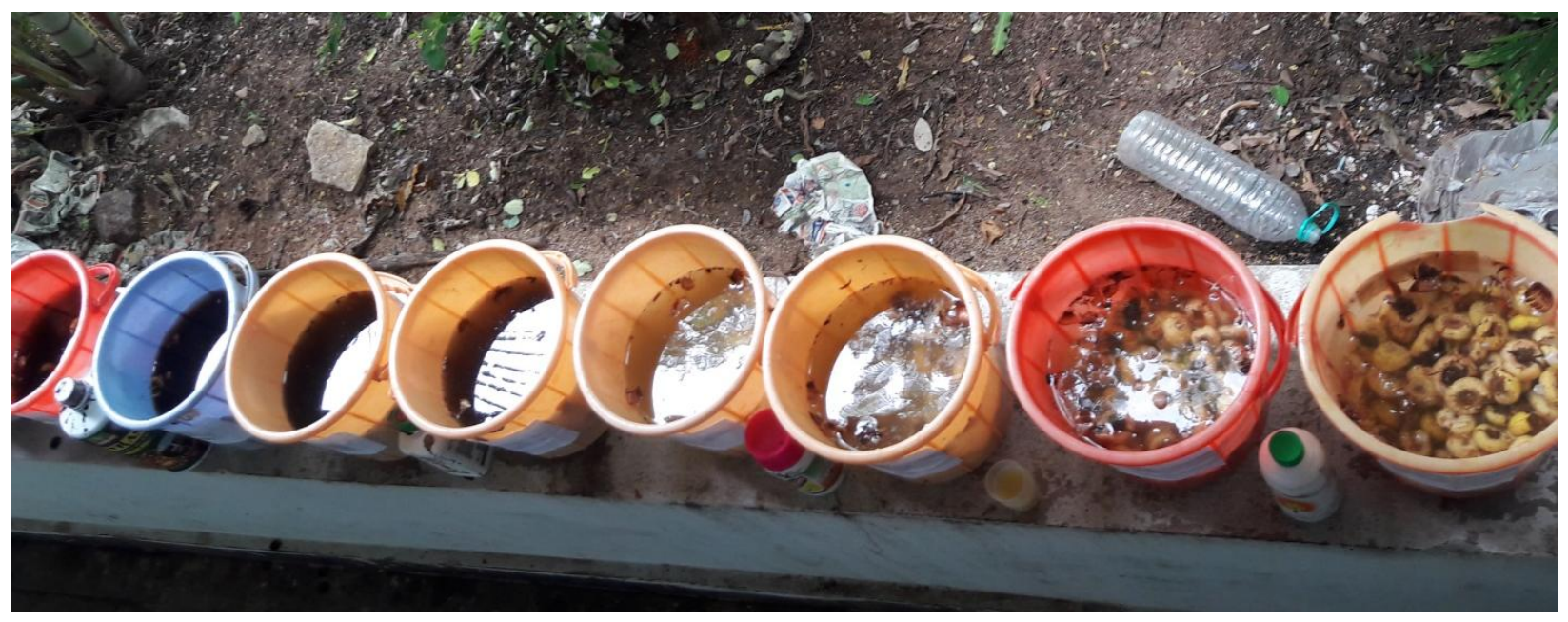

Vegetative growth of cut gladiolus cv.Arkaamar

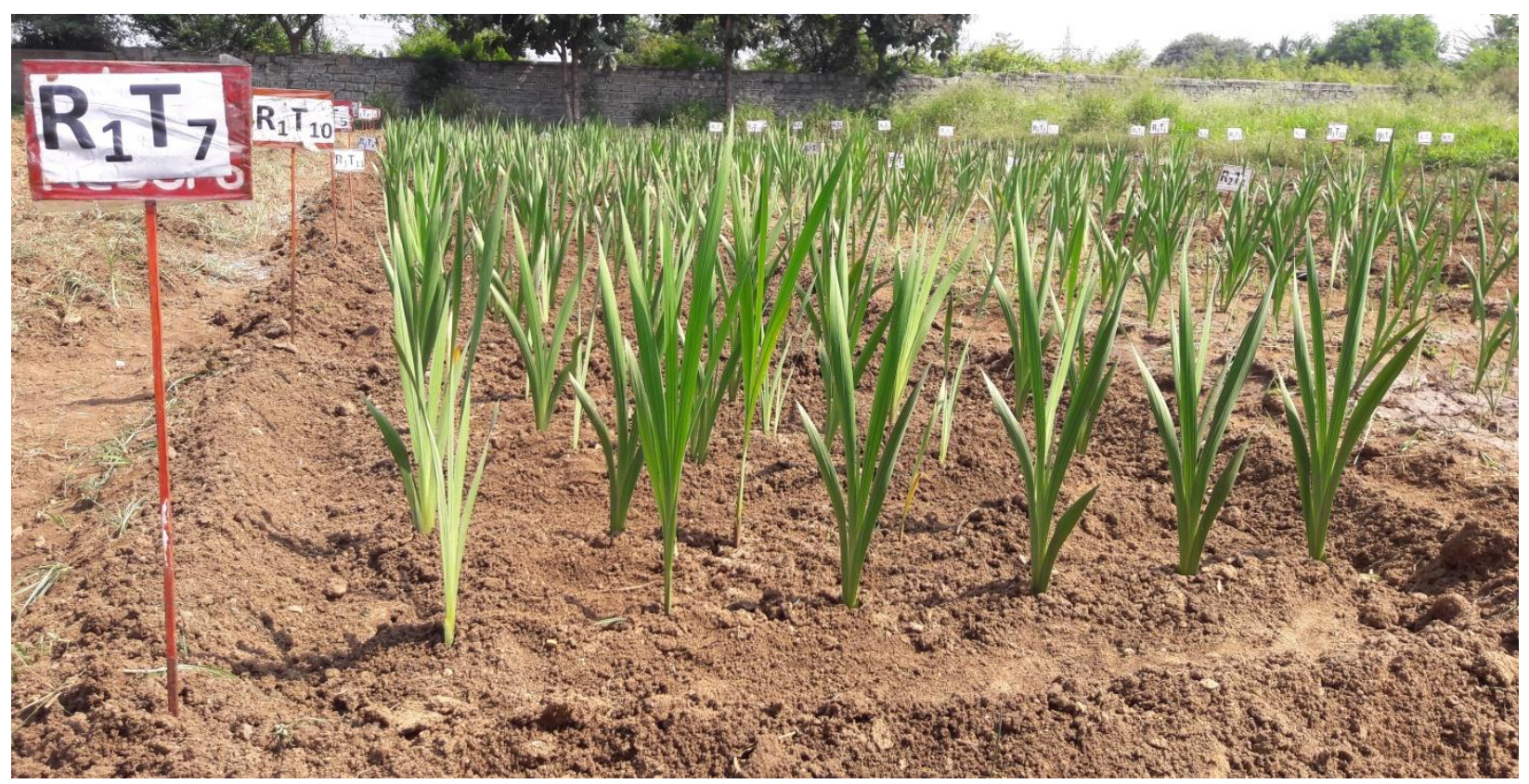




\section{Biostimulantsprays 30 days after corm sowing}

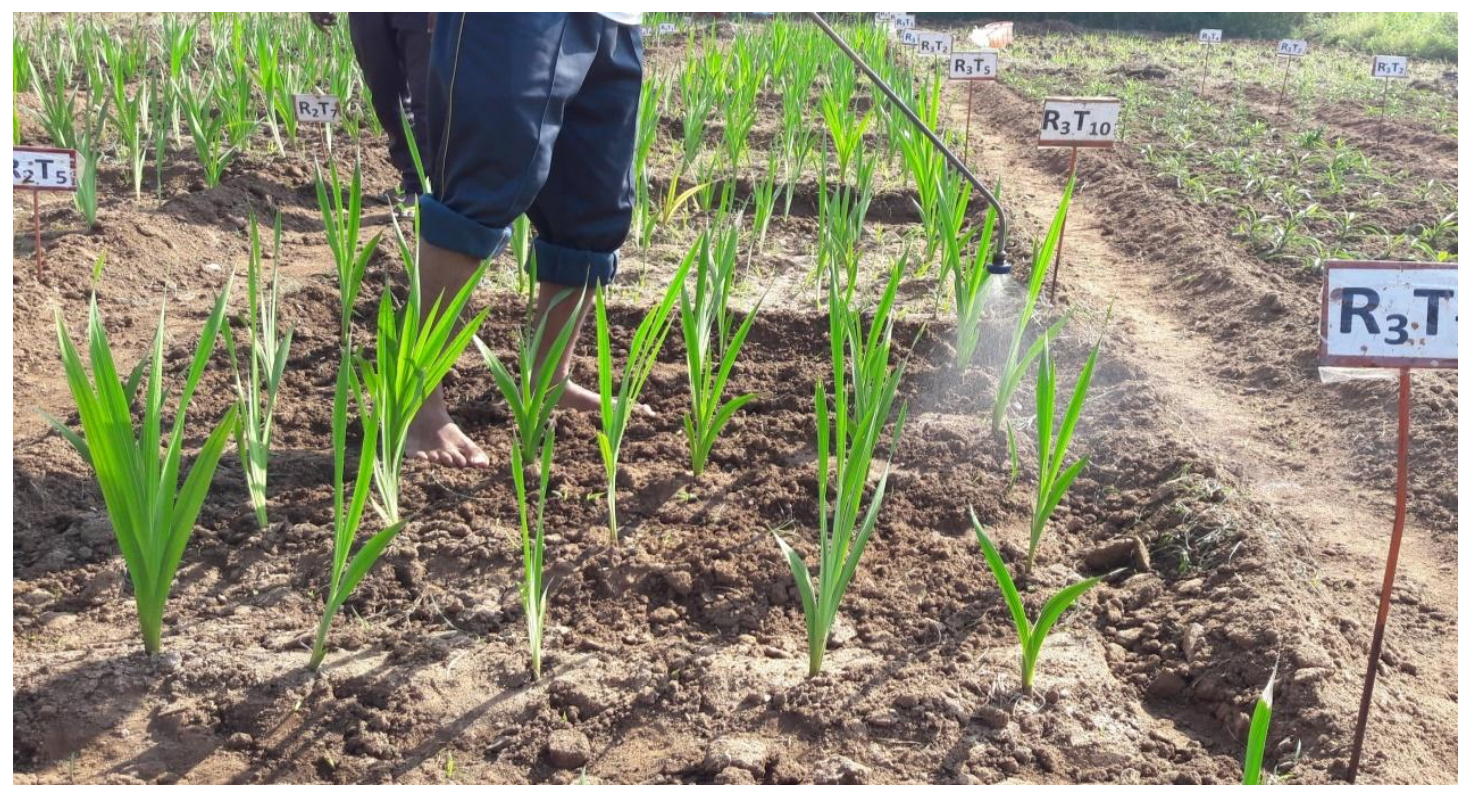

Over view of experimental site

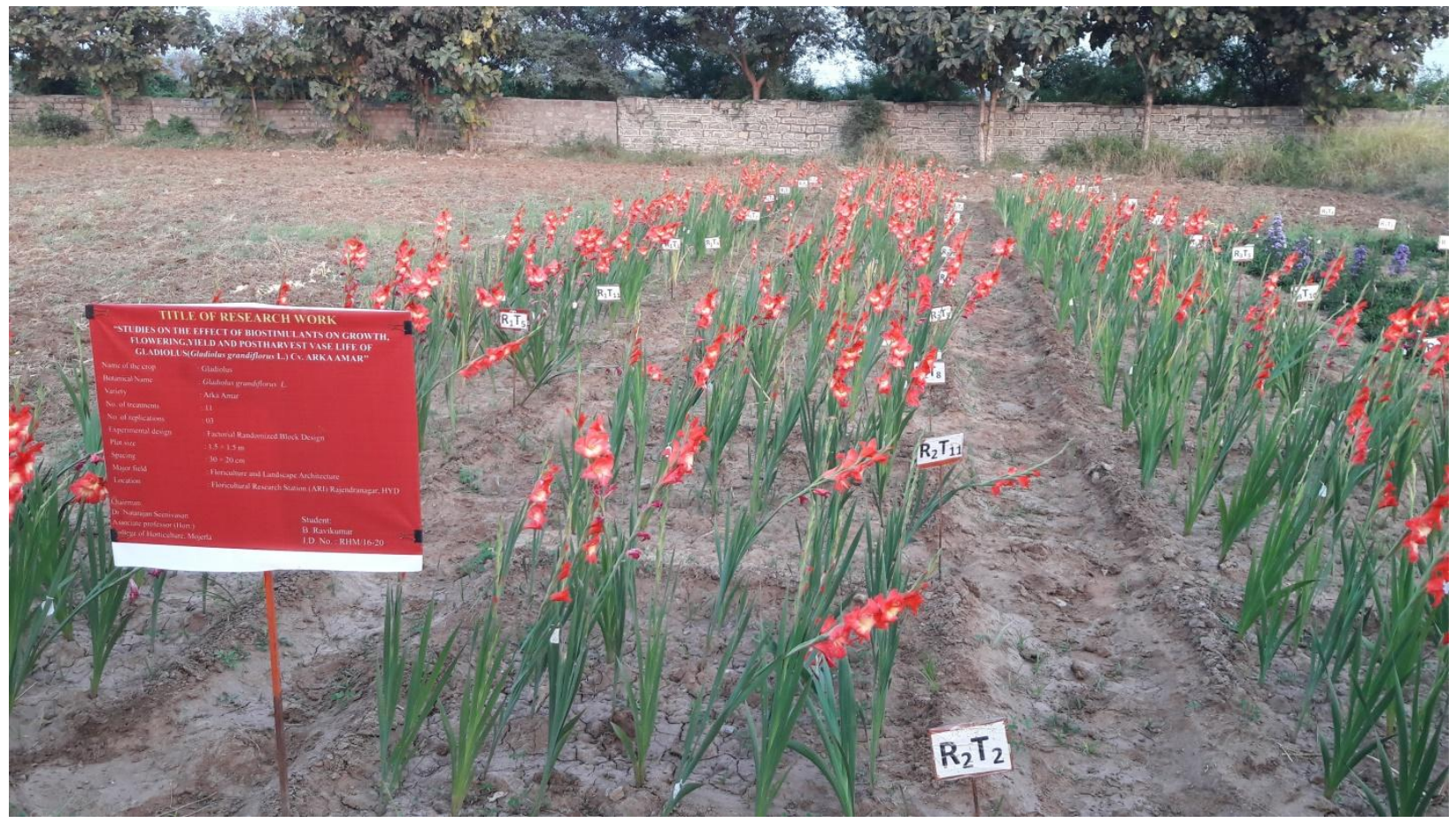

The data significantly revealed that maximum floret count spike ${ }^{-1}$ was recorded in treatment $\mathrm{T}_{8}$ (13.60) which was followed by Fulvic acid $2 \mathrm{ml} / \mathrm{l}$ (13.10) depicted in fig.4. It might be due to inhibition of peroxidase activity by humic acid due to auxin breakdown promoting the number of florets, these results are similar findings of Muscoloet al., (1993).Production of larger floret $(8.73 \mathrm{~cm})$ and maximum length of floret $(9.90 \mathrm{~cm})$ was recorded over the control when applied humic acid at $4 \mathrm{ml} / 1$ represented in fig.5. It might be due to 
gibberellin like activity of humic acid, these are confirmation with findings of Vaughan (1974); Naik and Jature (2010).

A critical examination of the data revealed that, maximum fresh weight of floret (3.73 g)was recorded with foliar spraying of Humic acid at $4 \mathrm{ml} / \mathrm{l}$, it may be due to humic substances increasing the growth and providing a greater fresh weight of floret (Canellas et al., 2000). Similar findings were observed by Baldotto et al., (2013).The maximum duration of flowering was recorded in the plants treated with Humic acid at $4 \mathrm{ml} /$ li.e $\mathrm{T}_{8}$ (16.53 days) which was followed by Humic acid at $2 \mathrm{ml} / 1-\mathrm{T}_{7}$ (14.80 days). It might be due to presence of humates which enhanced nutrient uptake, improved soil structure (Gupta et al., 2013) in chrysanthemum. Among the treatments tried, the treatment humic acid at $4 \mathrm{ml} / \mathrm{li}$.e $\mathrm{T}_{8}$ showed maximum spike longevity on the plant (18.32 days).This might be attributed due to the entry of humic acid into the plant, which might have altered the carbohydrate metabolism of plants promoting the accumulation of sugar (Cacco and Dell Agnola1984).

Gladiolus Cv. Arkaamar plants treated with Humic acid $4 \mathrm{ml} / \mathrm{li}$.e $\mathrm{T}_{8}$ foliar spray produced significantly maximum number of spikes plant $^{-1}$ (2.0)an increased in the number of spikes per plant due to Humic acid which consisted of active phenolic group would have inhibited oxidase activity and promoted the prolonged persistence of IAA in plants that might have contributed to the increased yield of spike as opined by Muscoloet al., (1993).Maximum number of spikes per plot and hectare $41.33 \& 183703.53$ respectively) was recorded in Humic acid $4 \mathrm{ml} / 1-\mathrm{T}_{8}$ which was followed by Humic acid at $2 \mathrm{ml} / 1$ depicted in fig.6.The obtained result might be due to the organic acids present in humic acid inhibit IAA oxidase enzyme and thereby increased the flowering process with effective auxin activity (Padmapriya, 2000).These findings are in agreement with SubeshRanjith Kumar (2003) in Chrysanthemum.

From the current study it can be concluded that application of cormpre soaking and foliar sprays withHumic acid at $4 \mathrm{ml} /$ li.e $\mathrm{T}_{8}$ appears to be an optimum treatment for enhancing growth and flowering of cut gladiolus $\mathrm{Cv}$. Arkaamar.

\section{References}

Ahmad, I., Saquib, R. U., Qasim, M., Saleem, M., Khan, A. S., and Yaseen, M. 2013.Humic acid and cultivar effects on growth, yield, vase life, and corm characteristics of gladiolus.Chilean Journal of Agricultural Research.,73(4).

Azza, A. M., Mazhar, Shaymaa, I., Shedeed, N. G., Abdel, A., Mona, H. and Mahgoub. 2012. Growth, flowering and chemical constituents of Chrysanthemum indicumL. plant in response to different levels of humic acid and salinity. Journal of Applied Sciences Research., 8(7):3697-3706.

Baldotto, M. A. and Baldotto, L. E. B. 2013.Gladiolus development in response to bulb treatment with different concentrations of humicacids.RevistaCeres., 60(1):138142.

Bashir, M., Qadri, R. W. K., Khan, I., Zain, M., Rasool, A., and Ashraf, U. 2016. Humic acid application improves the growth, floret and bulb indices of gladiolus (gladiolus grandiflorus L.) Pakistan Journal of Science., 68(2).

Cacco, G. and Agnola, G. D. 1984. Plant growth regulator activity of soluble humic complexes. Can.J.Soil Sci., 64(2):225-228.

Canellas, L. P., Berner, P. G., Silva, S. G., Silva, M. B and Santos, G. A. 2000. 
Fractions of organic matter in six soils of a topos sequence in the state of Rio de Janeiro. Pesq. Agropec. Bras., 35:133-143.

Cosenova, D. F. E., Arguello, J. A., Abdulla, G. and Orioli, G. A. 1990.Content of auxin inhibitor and gibberellinlike substances in humicacids.Biol. Pl., 32(5):346-351.

Gupta, V. N, Chakrabarty, D. and Datta, S. K. 2013. Influence of different holding solutions on post-harvest behavior of cut flowers: Chrysanthemum (Dendranthema grandifloraTzevlev). J. Orn. Hort., 9(2):80-84.

Kauffman, G. L., Kneivel, D. P., Watschke, T. L. 2007. Effects of a biostimulant on the heat tolerance associated with photosynthetic capacity, membrane thermostability, and polyphenol production of perennial ryegrass. Crop Sci., 47:261-267

Mato, M. C. and Mendez, J. 1970. Effect of humic substances on some enzyme activities. Geoderma., 3:255.

Muscolo, A., Felici, M., Concheri, G. and Nardi, S. 1993. Effect of earthworms, humic substances on esterase and peroxidase activity during growth of leaf explants of Nicotianaplum baginifolia. Biol.Fertil.Soils., 15(2): 127-131.

Naik, P. G and Jature, S. D. 2010.Effect of bioenzymes on flower quality, yield and vase life of rose (Rosa indicaL.) Cv. Gladiator. The Asian Journal of Horticulture., 4(2):311-313.

Padmapriya, S. 2000. Effect of gibberellic acid and certain other chemicals on the cutflower production of chrysanthemum

(DendranthemagrandifloraTzelev.) cultivars. M.Sc., (Hort) Dissertation submitted to Tamil Nadu Agrl. University, Coimbatore.

Panse, V. G. and Sukhatme, P. V. 1985.Statistical Methods for Agriculture Workers. ICAR, New Delhi, 14-33.

Pritam, S., Garg, V. K., and Kaushik, C. P. 2010. Growth and yield response of marigold to potting media containing Vermicompost produced from different wastes. Environmentalist., 30(2):123-130.

Sadhu, M. K. and Bose, T. K. 1973.Tuberose for most artistic garlands. Indian Horticulture., 18:17-21.

SubeshRanjith Kumar, C. 2003. Studies on standardization of package of practices for cut chrysanthemum (Dendranthema grandifloraTzvelev) cv. Yellow Regan under protected cultivation. Ph. D Thesis, Tamil Nadu Agricultural University, Coimbatore.

Vaughan, D. 1974. Effects of hydroxyproline on the growth and cell wall protein metabolism of excised root segments of Pisum sativum. Planta (Berl.), 115(2):135-145.

Vaughan, D., Malcolm, R. E. and Ord, B. G. 1985. Influence of humic substances on biochemical processes in plants. In: Soil organic matter and biological activity (Ed. Vaughan, D. and Malcolm, R. E.). Martinus Nijhoff, Dordrecht., 77-108.

\section{How to cite this article:}

Ravikumarbolagam and Seenivasan Natarajan 2019. Effect of Biostimulants Sprays on Growth and Flowering of Cut Gladiolus (Gladiolus grandiflorus L.) Cv. Arkaamar. Int.J.Curr.Microbiol.App.Sci. 8(09): 1742-1751. doi: https://doi.org/10.20546/ijcmas.2019.809.197 